\title{
FEMINISME MARXIS DALAM NOVEL TEMPURUNG KARYA OKA RUSMINI
}

\author{
Gaudensia Ratna Sari \\ (Pendidikan Bahasa Indonesia, Fakultas Keguruan dan Ilmu Pendidikan, Universitas \\ PGRI Adi Buana Surabaya) \\ gaudensiaganggu@gmail.com
}

\section{Agung Pramujiono}

(Pendidikan Bahasa Indonesia, Fakultas Keguruan dan Ilmu Pendidikan, Universitas

PGRI Adi Buana Surabaya)

agungpramujiono@unipasby.ac.id

\begin{abstract}
This study aims to describe Marxist feminism in Tempurung novels by Oka Rusmini. Marxist feminism is a problem related to social classes in the family and society. Marxist feminism is important to study, because in family life and in people's lives there are so many problems related to social classes especially those that occur in women. This research is a qualitative research with descriptive method. the data from this study are in the form of sentences that contain quotations containing Marxist feminism. The data source of this research is the Tempurung novel by Oka Rusmini. The technique used in collecting data is documentation techniques, because it collects data from written information in the form of Tempurung novels by Oka Rusmini. The results of this study of Marxist feminism show that in family life and in society there are still differences in social classes, especially in women. In this case women experience various kinds of problems, such as: women's position based on socio-economic and women's position based on social class in society. The position of women based on socioeconomic conditions includes economic exploitation of employment and economic exploitation of marriage. Whereas the position of women based on social class in society includes class differences in family and class differences in society.
\end{abstract}

Keywords: Feminism, Marxist, novel.

\section{PENDAHULUAN}

Karya sastra adalah seni bahasa yang bernaung di bawah payung imajinasi. Berbagai masalah dalam kehidupan difiksikan sesuai dengan pemikiran, keyakinan, keinginan, dan fantasi penciptanya. Karya sastra tersebut lahir sejalan dengan munculnya bahasa yang di pakai umat manusia, baik lisan maupun tertulis. Oleh karena itu, karya sastra juga berkembang sejalan dengan kebudayaan manusia. Semakin maju kebudayaan manusia semakin maju kesusastraannya. Sastra merupakan bagian tak terpisahkan dari keberadaan manusia sebagai homo estestis dan homo ludens, yaitu makluk berakal budi yang memiliki naluri keindahan dan naluri untuk menggunakan segala sesuatu untuk bermain sehingga menyenangkan. Dalam konteks seperti ini keberadaan sastra sama tuanya dengan keberadaan manusia di muka bumi. Tentu saja sastra harus diberikan batasan yang lebih leluasa. Sastra bukan hanya yang berbentuk buku atau kisah-kisah yang sudah tertata dengan baik (Shoim, 2013:1-2) 
Pada dasarnya karya sastra merupakan suatu pengungkapan kehidupan lewat bentuk bahasa. Hal ini sesuai dengan pendapat Teeuw (1984:22) yang mengatakan, bahwa Usaha lain untuk mendapatkan batasan sastra sebagai suatu gejala umum yaitu dengan mendekati dari namanya meskipun biasanya batasan itu tidak sempurna karena batasan itu harus diperluas dan diperketat apabila gejala itu akan dibicarakan secara ilmiah. Namun manfaat tinjauan dari pemakaian bahasa sehari-hari sebagai titik tolak cukup memadai.

Karya sastra digunakan pengarang untuk menyampaikan segala pikirannya tentang sesuatu yang ada dalam realitas yang dihadapinya. Realitas dalam kehidupan ini merupakan salah satu faktor pengarang untuk menciptakan sebuah karya sastra, di samping unsur imajinasi. Untuk mengetahui pikiranpikiran pengarang yang terdapat dalam karyanya, sastra dapat dibahas berdasarkan dua hal, yaitu bentuk dan isi. Dari segi isi, sastra membahas tentang suatu hal yang terkandung di dalamnya, sedangkan dari segi bentuk, sastra membahas cara penyampaiannya. Menurut genrenya, karya sastra dapat dibagi menjadi tiga, yaitu: prosa (fiksi), puisi, dan drama. Dari ketiga jenis genre sastra tersebut, penulis hanya memfokuskan kajian pada prosa fiksi.

Seorang penyair besar romawi yaitu Horatius (65-6 SM) mengatakan bahwa karya sastra harus mempunyai tujuan dan fungsi utile (bermanfaat) dan dulce (nikmat). Bermanfaat dalam arti pembaca dapat menarik pelajaran yang berharga dalam membaca karya sastra, yang mungkin bisa menjadi pegangan hidupnya karena mengungkapkan nilai-nilai luhur. Mungkin juga karya sastra itu mengisahkan hal-hal yang tidak terpuji, tetapi bagaimanapun pembaca masih bisa menarik pelajaran darinya sebab dalam membaca dan menyimak karya sastra pembaca dapat ingat dan sadar untuk tidak berbuat demikian. Selain itu, sastra harus bisa memberi nikmat melalui keindahan isi dan gaya bahasanya.

Jelaslah bahwa sastra tidak dapat dipisahkan dari kehidupan sosial dan budaya masyarakat. Lewat sastra dapat diketahui pandangan suatu masyarakat, sastra juga mewakili kehidupan dalam arti kenyataan sosial (Rene Wellek dan Austinn Warren, 1995: 15).

Sehubungan dengan pandangan tersebut, maka hubungan antara sastra dengan masyarakat inilah, sebenarnya yang menjadi dasar timbulnya masalah apresiasi sastra itu (Nafron Hasyim, 1987: 57). Berpedoman pada apresiasi yang menjadi sandaran dalam menggauli karya sastra dengan sungguhsungguh, sehingga timbul pengertian, penghargaan, kepekaan perasaan dan pikiran positif terhadap karya sastra.

Menurut Waluyo (2005:1), ada tiga bentuk karya sastra, yaitu prosa, puisi, dan drama. Contoh prosa, yaitu dongeng, cerpen, novel, dan novelet. Contoh puisi, yaitu pantun, syair, dan sebagainya. Contoh drama, yaitu komedi, tragedi, sendratari, dan sebagainya.

Sebagai salah satu karya sastra, novel adalah karangan prosa yang panjang mengandung rangkaian cerita kehidupan seseorang dengan sekelilingnya, dengan menonjolkan watak dan sifat setiap pelaku. Kata novel berasal dari italia novella yang berarti sebuah kisah atau sepotong berita.

Novel dikaji dalam dua unsur, yaitu unsur instrinsik dan unsur 
ekstrinsik. Unsur instrinsik meliputi alur, tokoh, latar, tema dan sudut pandang. Unsur intrinsik adalah unsur pembangun karya sastra yang bersifat otonom. Unsur intinsik terdapat di dalam karya satra itu sendiri, sehinga lepas dari permasalahan yang terkait dengan pengarang, stuktur sosial, pembaca, sosial politik, sosial ekonomi, dan moral.

Unsur ekstrinsik itu sendiri mencakup pendidikan, sosial budaya, sosial masyarakat, politik, ekonomi, adat, filsafat, ilmu pengetahuan, hukum dan seterusnya. Hal tersebut disebabkan karena prosa adalah potret realita sosial maka aspek ekstrinsiknya mencakup semua komponen kehidupan itu sendiri. Seorang pembaca penting untuk menyadari bahwa karya sastra tidak bisa lepas dari faktor luar, yitu feminisme.

Secara sederhana feminisme dapat dipahami sebagai suatu aliran pemikiran yang menghendaki kesetaraan antara laki-laki dan perempuan. Dalam pandangan kaum feminisme, masyarakat pada umumnya memperlakukan perempuan sebagai makhluk yang lebih rendah daripada laki-laki. Perlakuan ini terjadi terus menerus sampai menjadi kebiasaan yang mendarah daging sehingga jika derajat laki-laki lebih tinggi darpada perempuan, itu tidaklah dipandang aneh. Sebaliknya, jika derajat perempuan lebih tinggi darpada lakilaki, malah dianggap aneh dan tidak normal. Kehidupan semacam inilah yang yang disebut dengan istilah patriarkat. Tentu saja dalam masyarakat patriarkat penindasan atau subordinasi terhadap perempuan tidak mesti terjadi secara kasar, tetapi lebih sering secara halus. Menurut kaum feminis, cara-cara penindasan yang halus semacam ini juga terjadi di segala aspek kehidupan masyarakat, seperti dalam kehidupan ekonomi, politik, Pendidikan, rumah tangga, kesenian, dan kesustraan (Zulfahnur, dkk, 840-8.41).

Karya sastra yang bernuansa feminisme, dengan sendirirnya akan bergerak pada sebuah emansipasi. Kegiatan akhir dari sebuah perjuangan feminism adalah persamaan derajat, yang hendak mendudukan wanita tak sebagai obyek (Suwardi, 2013:149). Adapun aliran feminisme yang diusung oleh kaum feminisme yaitu: (a) feminisme liberal, (b) feminisme radikal, (c) feminisme sosialis, dan (d) feminisme marxis.

Feminisme Marxis merupakan gerakan memperjuangkan perlawanan terhadap sistem sosial ekonomi yang eksploitasi terhadap perempuan dan penindasan terhadap perempuan adalah bagian dari penindasan kelas dalam sistem produksi. Penindasan kelas khususnya dikaitkan dengan cara kapitalisme menguasai wanita dalam kedudukan-kedudukan yang di rendahkan.

Berbagai macam aliran feminisme memiliki perbedaan. Salah satunya aliran feminisme marxis yang pendekatan sastranya mengerucut kepada kelas-kelas sosial dan perempuan yang menjadi kelas tertindas. Pendekatan ini salah satunya dapat diterapkan pada novel berjudul "Tempurung" karya Oka Rusmini yang di dalamnya menceritakan kehidupan para perempuan yang berhadapan dengan tubuhnya, agama budaya dan masyarakat. cerita ini mengisahkan perempuan-perempuan yang hidup di dunia perkawinan yang absurd. Jauh di lubuk hati mereka tidak menginginkan perkawinan, tetapi di 
sisi lain mereka butuh anak, kasih sayang, cinta, perhatian dan sentuhan.

\section{METODE PENELITIAN}

Metode yang digunakan dalam penelitian ini adalah metode deskriptif, sedang pendekatan yang digunakan adalah pendekatan kualitatif. Data penelitian ini berupa kata-kata atau kalimat yang berkaitan dengan feminisme marxis. feminisme marxis terdiri dari dua bentuk yakni posisi perempuan berdasarkan fungsi sosial ekonomi dalam masyarakat dan posisi perempuan berdasarkan kelas sosial dalam masyarakat. posisi perempuan berdasarkan fungsi sosial ekonomi dalam masyarakat meliputi eksploitasi ekonomi dalam pekerjaan dan eksploitasi ekonomi dalam perkawinan. Sementara posisi perempuan berdasarkan kelas sosial dalam masyarakat meliputi dua hal yaitu perbedaan kelas dalam keluarga dan perbedan kelas dalam masyarakat. Sumber data dari penelitian ini adalah Novel Tempurung karya Oka Rusmini. Novel ini diterbitkan oleh PT Gramedia Widiasarana Indonesia tahun 2017 yang terdiri dari 404 halaman. Fokus penelitian adalah bentuk-bentuk feminisme marxis yang ada dalam novel Tempurung yang dikaji dengan teori feminisme Marxis. Teknik pengumpulan data dalam penelitian ini adalah teknik dokumentasi yaitu dengan membaca dan mencatat. Dalam pengumpulan data, peneliti menggunakan penandaan pada bagian-bagian tertentu dalam novel Tempurung karya Oka Rusmini untuk memudahkan proses analisis. Analisis data penelitian ini yaitu kualitatif deskriptif menganalisis menggunakan paragraf dan kalimat. Penggunaan kutipan-kutipan dalam novel juga diikutsertakan untuk mempermudah deskripsi data.

\section{HASIL DAN PEMBAHASAN \\ Bentuk-bentuk Feminisme marxis dalam Novel Tempurung karya Oka Rusmini.}

Feminisme marxis merupakan gerakan kaum prempuan untuk melakukan perlawanan terhadap tindakan kaum kapitalisme dan kaum patriarkat dalam melakukan penindasan. Hal ini terjadi karena adanya perbedaan kelas sosial antara kaum borjuis dan kaum proleter, serta adanya tindakan eksploitasi terhadap perempuan dalam sistem reproduksi. Adapun bentuk-bentuk feminissme marxis antara lain:

1. Posisi perempuan berdasarkan fungsi sosial ekonomi dalam msyarakat.

Novel Tempurung karya Oka Rusmini merupakan novel yang menjelaskan tentang bagaimana posisi perempuan dalam masyarakat. Dalam novel tempurung karya Oka Rusmini perempuan mengalami dua fungsi sosial ekonomi yaitu eksploitasi ekonomi dalam pekerjaan dan eksploitasi ekonomi dalam perkawinan.

\section{1) Eksploitasi Ekonomi dalam} Pekerjaan

Tokoh perempuan dalam novel ini adalah, Dayu, Saring, Glatik, Pidagda, Maya, Sipleg, Songi, Rimpig, Jelannga, Rosa, Nuryati, Nori, Zuraida dan Sara. Dari ke14 tokoh perempuan ada beberapa tokoh yang mengalami Ekploitasi ekonomi dalam pekerjaan yakni tokoh Saring, Sipleg dan Songi. Seperti dalam kutipan berikut 
"sejak kecil aku selalu ikut orang. Sering aku menangis sendiri bila ingat nasibku yang tidak jelas. Aku pernah jadi babu di rumah orang China, hanya untuk menamatkan sekolah dasarku. Kemudian jaga tokoh buah di pasar Bandung sampai tamat sekolah lanjutan. Pokoknya aku kerja serabutan untuk hidup itu sendiri. Sering aku mencoba mencari wujud ibubapak. Tak pernah muncul. Walaupun aku tahu, silsilah keluarga kacau. Penuh kepahitan dan keburukan. Juga penuh kutukan dan makian dari orang-orang desa di mana aku pernah lahir" (Rusmini, 2017:34).

Berdasarkan kutipan tersebut tampak bahwa tokoh Saring mengalami eksploitasi ekonomi pekerjaan. Dimana sejak kecil kehidupan Saring penuh dengan kepahitan dan keburukan. Ia harus menjadi babu hanya untuk menamatkan sekolah dasarnya. Selanjutnya menjual buah di pasar sampai tamat sekolah lanjutan serta pekerjaan serabutan lainnya. hal itu ia lakukan karena kehidupan ekonominya yang tidak memungkinkan. Dalam kutipan tersebut juga dijelaskan bagaimana Saring menjani kehidupannya yang penuh dengan kutukkan dan makian dari orang-orang desa dimana ia dilahirkan. Semua itu disebabkan karena kehidupan keluarganya yang sangat kacau balau.

\section{2) Eksploitasi Ekonomi dalam perkawinan \\ Dalam novel Tempurung karya Oka Rusmini juga}

menggambarkan

bahwa perempuan juga mengalami Eksploitasi bukan hanya dalam bidang pekerjaan tetapi juga dalam bidang perkawinan. Perempuan juga dijadikan sumber yang dapat menghasilkan uang dalam perkawinannya. Pada posisi ini terlihat jelas bahwa perempuaan hanya di manfaatkan tanpa ada keuntungan.

"Aku memutuskan membuka warung. Modal kupinjam dari Glatik. Jam tiga aku sudah bangun. Belanja beragam sayur dan lauk.

\section{"Warungku laris. Aku terus bekerja keras. Rumah kuperbaiki aku juga membuat sanggah, tempat persembahyangan di atas rumah. Cicilan rumah aku yang melunasi seluruhnya. Jam 10 aku sudah seperti babi, ngorok. Terjaga selalu pukul tiga. Aku sampai lupa punya suami. Entaah apa yang ada diotakku. Aku terus bekerja dan bekerja" (Rusmini, 2017:53)}

Pada kutipan tersebut terlihat bahwa Saring mengalami eksploitasi ekonomi dalam bidang perkawinan. Hal itu dibuktikan dengan Saring yang harus membuka warung untuk untuk membiayai kebutuhan seharihari. Ia harus bekerja dari subuh sampai jam sepuluh malam. Ia harus bekrja keras untuk memperbaiki rumahnya, membuat sanggah serta membayar cicilan rumah dan melunasi selurunhya. Meskipun ia tahu jika suaminya mempunyai simpanan. Tapi hal itu tidak membuat saring untuk berhenti bekerja. Hingga 
membuat Saring lupa jika ia mempunyai suami.

\section{Posisi Perempuan Berdasarkan Perbedaan Kelas Sosial Dalam Masyarakat.}

Setelah penulis memaparkan posisi perempuan berdasarkan fungsi sosial ekonomi dalam masyarakat, dalam bagian ini akan dijelaskan pula tentang posisi perempuan berdasarkan perbedaan kelas sosial dalam masyarakat. perbedaan kelas sosial dalam masyarakat sering kali terjadi. Hal serupa juga di alami oleh tokoh perempuan dalam novel Tempurung karya Oka Rusmini. Posisi perempuan berdasarkan perbedaan kelas sosial ini ada dua bentuk yakni, perbedaan kelas di dalam keluarga dan perbedaan kelas di dalam masyarakat.

\section{1) Perbedaan kelas dalam keluarga}

Sistem kelas yang berdasarkan pemilikan pribadi, secara inheren bersifat menindas dan kaum lelaki selalu di nomorsatukan sementara kaum perempuan selalu di nomorduakan dalam struktur keluarga dan di tempat kerja. kaum perempuan dalam novel Tempurung karya Oka Rusmini mengalami penindasan berdasarkan kelas sosial dalam keluarga. hal itu dibuktikan pada kutipan berikut.

"Aku tidak bisa seperti ini terus menerus-menerus, duduk diaam menunggumu pulang dengan mendengarkan Meme, ibumu, selalu mengeluh di kupingku. Mengatakan aku perempuan miskin yang tidak menguntungkan! Perempuan penuh kutukan yang biasa menular seluruh hidup keluarga suaminnya" (Rusmini, 2017:78)
Dalam kutipan tersebut dijelaskan bagaimana Sipleg menjalani hidupnya yang selalu mengalami penindasan dalam keluarga suaminnya. Hal ini terlihat dari sikap Ibu mertua Sipleg yang selalu menghina Sipleg dan menganggap Silpeg sebagai perempuan yang membawa kesialan dalam kehidupan keluarga ibu mertuanya. Di sini Sipleg juga selalu mendapat cemoohan dari ibu mertuanya yang mengatakan Sipleg sebagai perempuan yang hidupnya penuh dengan kemiskinan serta diliputi banyak kutukkan. Yang membuat kehidupan suaminya tidak baik.

\section{2) Perbedaan kelas dalam masyarakat}

Perbedaan kelas bukan hanya terjadi dalam kehidupan keluarga saja melainkan juga dalam kehidupan bermasyarakat. Dalam kehidupan bermasyarakat masih ditemukan permasalahan-permasalahan yang berkaitan dengan kelas sosial. perbedaaan kelas sosial dalam masyarakat ini lebih cenderung terjadi pada kaum perempuan. Seperti halnya yang dialami oleh kaum perempuan dalam novel tempurung. Hal itu dapat kita lihat dalam kutipan berikut ini.

"Ketika kau masih seorang kanakkanak menjelma perempuan dewasa, banyak problem datang. Pertama, problem pada tubuhmu. Kedua, problem dengan lingkungan. Karena tubuhmu makin dewasa, beragam aturan di tanam masyarakat di tubuh kita. Tidak boleh ini, tidak boleh itu, ini tabu, ini terlarang. Pokoknya banyak aturan. Semua menghukum. Semua menghina. Kalau perempuan kecil tiba-tiba hamil, lelaki yang menghamilinya masih bisa sekolah. Sedangkan si 
perempuan? Harus dikeluarkan dari sekolah. Belum lagi hukuman dari masyarakat. Dianggap perempuan gatal! Citra inilah yang terus melekat padanya. Perempuanlah korbannya. Sementara lelaki yang menghamilinya itu mungkin sudah jadi sarjana, atau sudah bekerja mapan dan punya istri dan anak. Sepertinya masa lalu mereka tidak pernah ada" (Rusmini2017:188)

Berdasarkan kutipan tersebut dapat dilihat bahwa kaum perempuan mengalami permasalahan kelas dalam masyarakat. dimana kaum perempuan sangat terikat dengan peraturanperaturan yang ada dalam masyarakat. kaum perempuan dilarang untuk melakukan segala sesuatu apabila hal itu merupakan suatu aturan yang telah diterapkan. Dalam kehidupan bermasyarakat apabila seorang anak permpuan hamil diluar nikah makai a tidak boleh melanjutkan Pendidikannya. Sementara laki-laki yang menghamilinya bisa melanjutkan pendidikannya ke jenjang yang lebih tinggi. Selain itu juga kaum perempuan yang melanggar aturan yang sudah diterapkan maka, perempuan itu akan dianggap perempuan yang tidak baik atau perempuan yang tidak bermoral.

\section{SIMPULAN}

Posisi perempuan dalam masyarakat maupun keluarga sangat rendah. Hal ini disebabkan karena adanya perbedaan pandangan antara kaum laki-laki dan kaum perempuan. Hal ini dissebabkan karena adanya pandangan bahwa kaum laki-laki sebagai modal reproduksi sedangkan perempun hanya berurusan dengan urusan domestik. Posisi perempuan sebagai fungsi sosial ekonomi meliputi, eksploitasi ekonomi pekerjaan dan eksploitasi ekonomi perkawinan.

Posisi perempuan berdasarkan perbedaan kelas sosial dalam masyarakat terjadi karena adanya nggapan bahwa penindasan kelas khususnya perempuan. Penindasan ini dikaitkan dengan cara kapitalis menguasai dalam kedudukan yang direndahkan. Perempuan dianngap sebagai manusia nomor dua atau perempuan kelas bawah yang tidak memiliki hak-hak pribadinya. Di sini wanita mengalami ketidakdilan berdasarkan jenis kelamin. Posisi perempuan berdasarkan kperbedaan kelas sosial dalam masyarakat meliputi. Perbedaan kelas dalam keluarga daan perbedaan kelas dalam masyarakat.

\section{DAFTAR PUSTAKA}

Anwar, Shoim. 2013. Sastra Lama. Jawa Timur: Pustaka Ilalang.

Endraswara, Suwardi. 2013. Metodologi Penelitian Sastra. Yogyakarta: Center for Academic Publishing Service.

Farida, Yuli. 2015. Bentuk Feminisme Marxis Dalam Novel Gadis Budak Karya Buchi Emecheta. Skripsi: Universitas PGRI Adi Buana Surabaya.

Fakih, Mansour. 2008. Analisis

Gender dan Transformasi sosias. Yogyakarta:

INSISTPress

Moleong, Lexy. 2014. Metodologi

Penelitian Kualitatif.

Bandung: Remaja

Rosdakarya.

Nanik. 2016. Analisis Novel Kawin

Kontrak Karya Saifur Rohman

Berdasarkan Teori Feminisme

Marxis. Makalah. Universitas

Negeri Jakarta. 
https://www.google.co.id/amp /s/marxismedansastra.wordpre ss.com/2016/06/24/analisisnovel-kawin-kontrak-karyasaifur-rohman-berdasarkanteori-feminisme-marxis/amp/ diunduh pada 23 agustus 2018, pukul 10.30.

Nurgiyantoro, Burhan. 2002. Teori Pengkajian Fiksi. Yogyakarta: Gadjah Mada University Press

Rusmini, Oka. 2017. Tempurung. Jakarta: Gramedia Widiasarana.

Semi, Atar. M. 1993. Anatomi sastra. Padang: Angkasa Raya.
Tarigan, Henry. Guntur. 1991. Prinsip-Prinsip Dasar Sastra. Bandung: Angkasa Bandung.

Tong, Rosemarie. 1998. Feminist Thought. Yogyakarta: Jalasutra Waluyo, Herman J.2005. Apresiasi Puisi. Jakarta: PT. Gramedia Pustaka Utama.

Wellek, Rene dan Austin Warren. 1989. Teori Kesusastraan (penerjemah Melani Budianta). Jakarta: PT Gramedia.

Zulfahnur, dkk. 2007. Teori Sastra. Jakarta: Universitas Terbuka. 